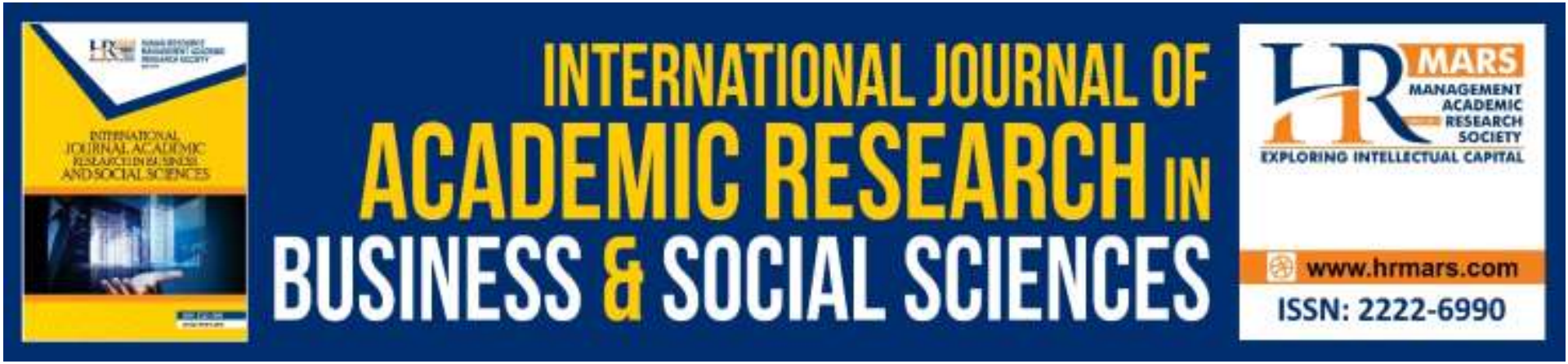

\title{
Government Sectoral Expenditure in Pension and Gratuities and its Implication to the Economy, Econometric Evidence from Nigeria
}

\author{
Ezema, Clifford Anene
}

To Link this Article: http://dx.doi.org/10.6007/IJARBSS/v9-i9/6275

DOI: $10.6007 /$ IJARBSS/v9-i9/6275

Received: 09 July 2019, Revised: 01 August 2019, Accepted: 30 August 2019

Published Online: 17 September 2019

In-Text Citation: (Ezema, 2019)

To Cite this Article: Ezema, C. A. (2019). Government Sectoral Expenditure in Pension and Gratuities and its Implication to the Economy, Econometric Evidence from Nigeria. International Journal of Academic Research in Business and Social Sciences, 9(9), 140-152.

Copyright: (C) 2019 The Author(s)

Published by Human Resource Management Academic Research Society (www.hrmars.com)

This article is published under the Creative Commons Attribution (CC BY 4.0) license. Anyone may reproduce, distribute, translate and create derivative works of this article (for both commercial and non-commercial purposes), subject to full attribution to the original publication and authors. The full terms of this license may be seen at: http://creativecommons.org/licences/by/4.0/legalcode

Vol. 9, No. 9, 2019, Pg. 140 - 152

http://hrmars.com/index.php/pages/detail/IJARBSS

JOURNAL HOMEPAGE

Full Terms \& Conditions of access and use can be found at http://hrmars.com/index.php/pages/detail/publication-ethics 


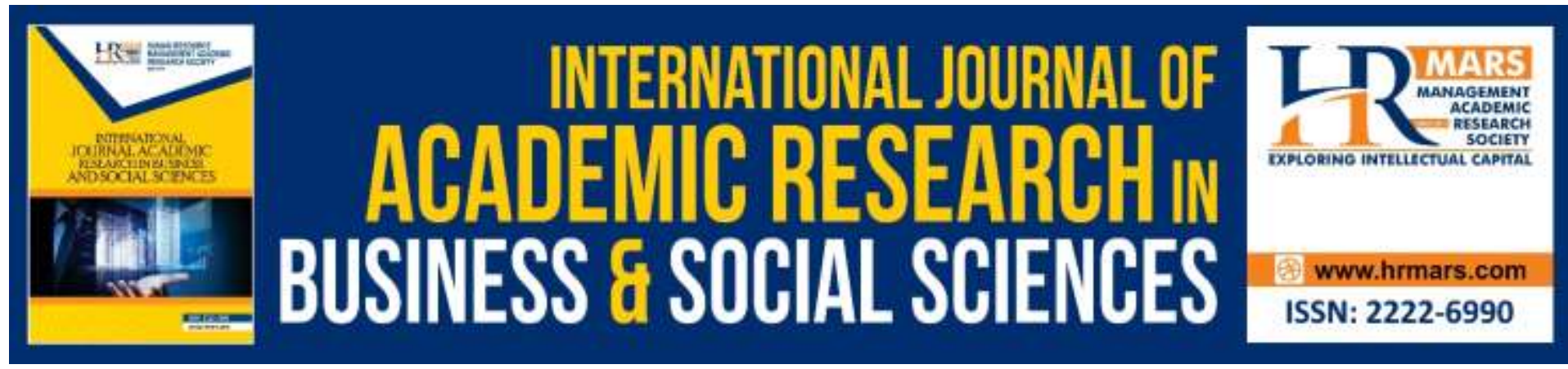

\title{
Government Sectoral Expenditure in Pension and Gratuities and its Implication to the Economy, Econometric Evidence from Nigeria
}

\author{
Ezema, Clifford Anene \\ Department of Insurance and Risk Management, Faculty of Management Sciences, Enugu, \\ State University of Science and Technology, (ESUT), ENUGU, \\ Email: Ezemaclifford10@gmail.com
}

\begin{abstract}
The study examined the responsiveness of economic growth to government expenditure in Nigeria. Specifically, the study investigated the responses of pensions and gratuities expenditure on real gross domestic product in Nigeria. Thus, pensions and gratuities served as the independent variables while real gross domestic product served as the dependent variable. The study covered the period 1981 to 2016 and data were collected from the Central Bank of Nigeria (CBN) Statistical Bulletin. To analyze the data, the study employed Ordinary least square model and the Error Correction Mechanism (ECM) technique as the analytical tool. Findings showed that pensions and gratuities expenditure of government has a positive and significant response on economic growth in Nigeria in the long run. The study recommends, amongst others, that the government should spend more on settling pensions and gratuities as a way to increase aggregate demand and foster more economic growth in Nigeria.
\end{abstract}

Keywords: Pension, Gratuity, Economic Growth, Responsiveness.

Introduction: The argument on whether or not government should spend and on what it should spend on has become a sour point in intellectual discourse (Okwo, 2011; Agu, Idike, Okwo \& Ugwunta, 2014; Samira, 2016; Nwaoha, Onwuka \& Ejem, 2017). Fundamentally, two questions have stood out in the course of these debates: One, should government spend? Two, if government should spend, on what should the government spend? Given the arguments of the Keynesians, government should naturally spend (Gilbert \& Kehinde, 2017). The Keynesian school of thought argued that since an economy is made up of four components namely consumption, investment, government and net export and all the four components are expected to work towards enhancing aggregate demand thereby leading to economic growth; it follows that if there is any failure from the other three components, government is alone and must naturally interfere to spur economic growth (Samira, 2016). For instance, if household consumption is adversely affected by economic upheavals, private investment declines through the fall in aggregate demand. Net export is also adversely affected and cannot spur economic growth in the face of economic distortions especially in 
nations that are import-dependent. Thus, government expenditure remains the fulcrum upon which economic growth can be actualized in the face of economic distortions (Cornelius, Nkamare \& Ogar, 2016).

In Nigeria, the government has over the years made expenditures aimed at boosting its economy. For example, capital expenditure made by government stood at 6.57 billion in 1981 and this increased to $\$ 8.53$ billion in 1986 although with some decreases in-between. By 2013, government capital expenditure had increased to an impressive $\$ 1,108.39$ billion (approximately N1.11 trillion). It dropped again to $\$ 6.37$ billion in 1987 but thereafter it assumed an upward trend such that it stood at 28.34 billion in 1991 . In 1994, capital expenditure increased to 70.92 billion and this impressive outlook continued with capital expenditure reaching $\$ 498.03$ billion in 1999 . Yet again, the downward government capital spending was recorded for the year 2000 with the capital expenditure dropping to $\$ 239.45$ billion from 498.03 billion in 1999 . These inconsistencies continued in the other years that followed with the capital expenditure reaching an all-time high of 1,152.80 billion in 2009 but yet decreased to 634.80 billion in 2016 (CBN, 2016). Overall, it is evident that although government has been making capital spending but this has remained largely inconsistent (and decreasing) in the years under review. In contrast, recurrent expenditure of government has grown steadily over the years such that it has generated so much hues and cries from Nigerians. The argument had been that increased (increasing) recurrent spending does not add any value and may not lead to economic growth. To determine the veracity or otherwise of this claim necessitated this study.

Government expenditure is usually made up purchases of goods and services and other forms of expenditure on final products plus the cost of living of government employees and transferred payments. Government expenditures became necessary following the perceived failure of market economy to effectively and efficiently allocate resources so as to achieve an all-inclusive economic growth. In carrying out these roles, there has been rapid expansion of government sector and by implication growth in government expenditure. Thus, the benefits of government expenditure cannot be overestimated since it is aimed at making public goods available to its citizens. In Nigeria, there is no denying the fact that government expenditure has continued to rise due to the huge receipts from production and sales of crude oil and the increased demand for public goods like roads, communication, power, education, health etc. Nevertheless, there is discordant feeling on whether increased government expenditures induce economic growth in Nigeria or not. Under normal circumstances, increased government expenditure is expected to induce economic growth. Hence, one may not but wonder if the economy would have grown more if the government had spent differently. Simply put, would the Nigerian economy have benefitted more if government expenditure had been channeled differently from what was done in the past. The objective of the study is to investigate the responsiveness of economic growth to pensions and gratuities expenditure in Nigeria. The study adopted data from 1981 to 2016. The year 1981 is considered as the base year for the study in order to capture both the pre-SAP era and post-SAP era. However, 2016 was chosen as the end-year for the study to capture the current trends in terms of both pensions and gratuities expenditures and economic growth in Nigeria. The second section of this work contains a review of empirical literature and section three contains the methodology with four presentation and analyses of data and five conclusions and recommendations. 


\section{Conceptual Review}

\section{Concept of Economic Growth}

Economic growth broadly refers to an increase in total value of goods and services produced in a country on annual basis (Nwaeze, Michael and Nwabekee, 2014). In relative and absolute terms, economic growth can be conceptualized as an increase in gross domestic product (GDP), gross national product (GNP) and National income (NI). Thus, economic growth represents an increase in size of national economies especially the gross domestic product per capita (GDP per capita) of individuals living in a country. Based on the foregoing, IMF (2013) classified economic growth as positive, negative and zero depending on the experiences of nations. For instance positive economic growth occurs when national annual average macroeconomic indicators exceed the average growth of the national population growth. Conversely, negative economic growth arises when the national annual average growth of macroeconomic indicators is less than the growth of the national population growth. Zero economic growth occurs when the growth of annual macroeconomic indicators is equal to the growth of the national population. In another sphere, economic growth is classified as either intensive or extensive. Economic growth is classified as intensive when an increase in economic growth is caused by more efficient use of inputs such as labour, physical capital, energy or materials. Nevertheless, extensive economic growth occurs when an increase in national growth is caused only by increase in the amount of inputs available for use (Bjork, 1999).

\section{Concept of Pensions and Gratuities Expenditures}

Pensions and gratuities expenditures are generally classified under transfer expenditure in that when the government makes such expenditures it does not earn any income in return but it carries out such expenditures in order to satisfy its obligations and often times end up offering welfare to the vulnerable segments of the society (Okemini\&Uranta, 2008). Other transfer expenditures include government expenditure on public debt servicing, interest payments, government expenditure on subsidies, government expenditures on unemployment allowances and government expenditure on welfare benefits (poverty alleviation programmes) etc.

\section{Theoretical Review}

\section{Keynesian Theory of Government Expenditure}

The Keynesian theory of government expenditure was postulated by British economist John Maynard Keynes and became popularized during the great Depression in the 1930s. The Keynesian theory is premised on four major assumptions and these assumptions distinguish the Keynesian school of thought from others. The assumptions include (i) government has a role (ii) fallibility of self-regulatory mechanism (iii) use of fiscal policies to boost the economy (iv) Causality runs from government expenditure to economic growth (Keynes, 1936). This theory favours the study since emphasis of the theory is on the role that government plays in achieving economic growth. This theory is particularly apt in the developing nations such as Nigeria where government is constitutionally saddled with the responsibility of providing public goods and services which are pivotal to achieving increased economic growth. 


\section{Empirical Review}

Kelvin, Yapatake and Abeid (2017) examined the effect of government expenditure on economic growth in Tanzania for the period 1996 to 2014. The study adopted foreign direct investment (FDI), total expenditure and gross domestic savings as the independent variables as well as proxies for government expenditure while GDP served as the dependent variable and measure for economic growth. The study employed Granger-Causality test and ECM as the analytical tools. Findings revealed based on the Causality test, that there exists unidirectional causality running from economic growth to government expenditure. In other words, economic growth in Tanzania determined the level of government expenditure. More so, the study revealed that both gross domestic savings and foreign direct investment do not have unidirectional causality relationship with GDP in Tanzania. Going by the ECM result, the study revealed that government expenditure has a positive but insignificant effect on economic growth in the short run and gross domestic savings has a positive but insignificant effect on economic growth in the short run. However, foreign direct investment has a negative and significant effect on economic growth in the short run. In the long run, the study revealed that total government expenditure has a positive and significant effect on GDP while both gross domestic savings and foreign direct investment have positive but insignificant effect on economic growth in Tanzania

. Obialor (2017) investigated the effect of government human capital investment on economic growth in sub-Saharan Africa. The study restricted itself to the use of data from South Africa, Nigeria and Ghana for the period 1980 to 2013. The study adopted three human capital investment variables namely health, education and literacy rate as the independent variables while real gross domestic product served as proxy for economic growth as well as the dependent variable. The Vector Error Correction Mechanism (VECM) and cointegration test were carried out in the study. Findings revealed that government expenditure on health and government expenditure on education have positive and significant effect on Nigeria's economy alone while literacy ratio has positive but insignificant effect on all the three countries.

Nwankwo, Kalu and Chiekezie (2017) investigated the impact of fiscal policy on economic growth in Nigeria from 1970 to 2014. The study adopted government capital expenditure, government recurrent expenditure, oil revenue and tax revenue as the independent variables while gross domestic product served as proxy for economic growth as well as the dependent variable. The study employed unit root test, Johansen cointegration test and ECM as the analytical tools. Findings revealed that one-year lagged capital expenditure has a positive but insignificant effect on economic growth while recurrent expenditure has a positive and significant effect on economic growth in Nigeria. However, two-year lagged recurrent expenditure has a negative and insignificant effect on economic growth while oil revenue and tax revenue have positive and significant effect on economic growth both in the short run and long run respectively. Lagged two-year tax revenue has a positive and insignificant effect on economic growth in Nigeria. On their part,

Nwaoha, Onwuka and Ejem (2017) examined the effect of aggregated and disaggregated government expenditure on economic growth in Nigeria for the period 1980 to 2015. The study adopted aggregated government expenditure (proxied by total federal government expenditure). Disaggregated expenditure was proxied by recurrent expenditure and capital expenditure while real gross domestic product served as proxy for economic growth. All of total government expenditure, recurrent expenditure and capital expenditure served as the 
independent variables while real GDP served as the dependent variable. The study employed the error correction mechanism (ECM) as the empirical tool of analysis. Findings showed that total federal government expenditure and capital expenditure have positive and significant effect on economic growth in Nigeria. On the other hand, the study revealed that recurrent expenditure has a positive and insignificant effect on economic growth in Nigeria.

Alshahrani and Alsadiq (2014) examined the relationship between government expenditure and economic growth in Saudi Arabia for the period 1970 to 2013. The study made use of government expenditures on education, defense, housing, private domestic investment, public domestic investment, and healthcare as proxies for government expenditure while gross domestic product stood as a proxy for economic growth. The study employed the vector error correction mechanism (VECM) as the empirical tool of analysis. Findings showed that private and public domestic investments and government expenditure on health have positive and significant relationship with economic growth in Saudi Arabia in the long run. In conclusion, the study argued that government expenditure has a positive strong significant effect on economic growth in Saudi Arabia. In the light of the unending debate,

Bazezew (2014) investigated the impact of government sectoral expenditure on economic growth in Ethiopia for the period 1975 to 2013. Government expenditure on defence, government expenditure on agriculture and government expenditure on health were adopted as proxies for government expenditure and these variables served as the independent variables. On the other hand, gross domestic product stood as the proxy for economic growth and it served as the dependent variable. The study employed the multivariate cointegration test and error correction mechanism (ECM) as the analytical tools. Findings showed that government expenditure on education has a positive impact on GDP (economic growth) in the long run while government expenditure exhibited a positive but insignificant relationship with GDP in the short run. In terms of defense, the study showed that a negative and significant relationship exists between government expenditure on defense and economic growth (GDP) in both the long run and short run. In agriculture, the study showed that there exists a negative and significant relationship between government expenditure on agriculture and economic growth in the long run; but a negative and insignificant relationship was seen between government expenditure on agriculture and economic growth in the short run. In health expenditure, the study revealed that a negative and insignificant relationship exists between government expenditure on health and economic growth in both the long run and short run. In conclusion, the study argued that government expenditure has a significant effect on economic growth in Ethiopia.

Wendewesen (2012) investigated the effect of government expenditure on GDP in Ethiopia for the period 1980 to 2011 . The study made use of government expenditure on education, government expenditure on road construction, government expenditure on health, government expenditure on agriculture and government expenditure on non-poverty sectors as proxies for government expenditure. All the above-listed government expenditures were used as the explanatory variables in the study while gross domestic product served as the dependent variable. The study employed the vector error correction mechanism (VECM) as the analytical tool. Findings showed that government expenditures on education and road construction have positive and significant impact on GDP in the short run. However, government expenditures on health, agriculture and non-poverty sectors have negative and insignificant effect on GDP. In conclusion, the study argued that government expenditure in general has a significant positive effect on economic growth in Ethiopia. 
Nworji and Oluwalaiye (2012) investigated the nexus between government spending on road infrastructure and its impact on the growth of Nigerian economy for the period 1980 to 2009. The study made use of government expenditures on road infrastructure, defense, transportation and communication and inflation rate as the independent variables. Gross domestic product served as the dependent variable. Ordinary Least Squares (OLS) multiple regression method was employed as the analytical tool. Evidence from the study showed that government expenditure on transport and communication has a positive and significant effect on economic growth in Nigeria. The study also revealed that government expenditure on defence has a positive and significant impact on economic growth while inflation rate has a positive and insignificant impact on economic growth in Nigeria.

\section{Research Gap}

This study brought to the fore an in-depth understanding of the effect of pensions and gratuities payments (expenditures) on economic growth in Nigeria which has not been existing.

\section{Methodology}

\section{Research Design}

The study adopted the ex-postfacto research design. The ex-post facto research design is considered in this study because there is already existing data which cannot be manipulated by the researcher.

\section{Nature and Data source}

The study made use of secondary data which were sourced from the Central Bank of Nigeria (CBN) Statistical Bulletin, volume 17, December 2016.

\section{Model Specification}

This study was anchored on the Keynesian theory which establishes the importance of government expenditure in achieving economic growth. In line with Okoro (2013) with modifications, the model for the study was specified as:

RGDP $=\int($ PENGEX)

Where

RGDP = Real gross domestic product (proxy for economic growth)

PENGEX = Pensions and gratuities expenditure

$\int=$ functional relationship notation

Transforming equation (1) into its linear econometric form, we obtained

RGDP $=\beta_{0}+\beta_{1}$ PENEX $+\mu_{t}$

Where

$\beta_{0}=$ constant term

$\beta_{1}=$ coefficient parameters of the explanatory variables

$\mu=$ stochastic error term

By a priori $\beta_{0}>0, \beta_{1}>0$.

Equation (2) was transformed into its natural logarithm form to make sure that all the variables bear a common base. With this, the regression equation becomes:

$\operatorname{LOG}($ RGDP $)=\beta_{0}+\beta_{1}$ LOG $\left(\right.$ PENGEX) $+\mu_{\mathrm{t}}$ 
INTERNATIONAL JOURNAL OF ACADEMIC RESEARCH IN BUSINESS AND SOCIAL SCIENCES Vol. 9, No. 9, September, 2019, E-ISSN: 2222-6990 @ 2019 HRMARS

Data Presentation and Analysis

Data Presentation

\begin{tabular}{|c|c|c|c|c|c|c|}
\hline YEAR & RGDP & PDSEX & PENGEX & LOGRGDP & LOGPDSEX & LOGPENGEX \\
\hline 1981 & $15,258.00$ & 1.03 & 0.21 & 4.18349773 & 0.011742571 & $\begin{array}{c}- \\
0.676971631 \\
\end{array}$ \\
\hline 1982 & $14,985.08$ & 1.17 & 0.24 & 4.17565902 & 0.06713264 & $\begin{array}{c}- \\
0.621581562 \\
\end{array}$ \\
\hline 1983 & $13,849.73$ & 1.01 & 0.21 & 4.14144116 & 0.00306318 & $\begin{array}{c}- \\
0.685651021 \\
\end{array}$ \\
\hline 1984 & $13,779.26$ & 1.24 & 0.25 & 4.13922575 & 0.091778715 & $\begin{array}{c}- \\
0.596935487 \\
\end{array}$ \\
\hline 1985 & $14,953.91$ & 1.61 & 0.33 & 4.17475485 & 0.205759328 & $\begin{array}{c}- \\
0.482954874 \\
\end{array}$ \\
\hline 1986 & $15,237.99$ & 1.63 & 0.33 & 4.18292761 & 0.212612277 & $\begin{array}{c}- \\
0.476101925 \\
\end{array}$ \\
\hline 1987 & $15,263.93$ & 3.93 & 0.09 & 4.18366634 & 0.594276478 & $\begin{array}{c}- \\
1.026842196 \\
\end{array}$ \\
\hline 1988 & $16,215.37$ & 9.24 & 0.96 & 4.20992689 & 0.965610865 & $\begin{array}{c}- \\
0.017095882 \\
\end{array}$ \\
\hline 1989 & $17,294.68$ & 13.27 & 0.70 & 4.23791243 & 1.122991998 & $\begin{array}{c}- \\
0.154529867 \\
\end{array}$ \\
\hline 1990 & $19,305.63$ & 23.82 & 0.74 & 4.28568405 & 1.37698369 & $\begin{array}{c}- \\
0.127960332\end{array}$ \\
\hline 1991 & $19,199.06$ & 26.41 & 0.79 & 4.28327997 & 1.42184075 & $\begin{array}{c}- \\
0.100836359\end{array}$ \\
\hline 1992 & $19,620.19$ & 19.40 & 19.05 & 4.29270322 & 1.287807451 & 1.279830389 \\
\hline 1993 & $19,927.99$ & 81.08 & 2.65 & 4.29946357 & 1.908922181 & 0.423496646 \\
\hline 1994 & $19,979.12$ & 49.40 & 1.73 & 4.30057643 & 1.693729724 & 0.237640879 \\
\hline 1995 & $20,353.20$ & 51.06 & 2.00 & 4.30863275 & 1.708067201 & 0.300356317 \\
\hline 1996 & $21,177.92$ & 53.05 & 0.00 & 4.32588332 & 1.724664905 & \#NUM! \\
\hline 1997 & $21,789.10$ & 68.54 & 0.00 & 4.33823925 & 1.835942435 & \#NUM! \\
\hline 1998 & $22,332.87$ & 64.39 & 0.00 & 4.34894448 & 1.808848965 & \#NUM! \\
\hline 1999 & $22,449.41$ & 30.84 & 0.00 & 4.35120493 & 1.489161945 & \#NUM! \\
\hline 2000 & $23,688.28$ & 131.05 & 17.04 & 4.37453353 & 2.117430457 & 1.231373809 \\
\hline 2001 & $25,267.54$ & 155.42 & 30.04 & 4.402563 & 2.191496341 & 1.477770704 \\
\hline 2002 & $28,957.71$ & 163.81 & 57.08 & 4.46176422 & 2.214343921 & 1.756502327 \\
\hline 2003 & $31,709.45$ & 363.51 & 34.16 & 4.50118867 & 2.560516742 & 1.533564204 \\
\hline 2004 & $35,020.55$ & 382.50 & 72.20 & 4.54432295 & 2.582634619 & 1.858542875 \\
\hline 2005 & $37,474.95$ & 393.96 & 84.05 & 4.57374105 & 2.595455546 & 1.924537718 \\
\hline 2006 & $39,995.50$ & 249.33 & 101.21 & 4.60201118 & 2.39676757 & 2.005216988 \\
\hline 2007 & $42,922.41$ & 213.73 & 106.14 & 4.63268408 & 2.329863047 & 2.02586558 \\
\hline 2008 & $46,012.52$ & 381.20 & 137.90 & 4.66287597 & 2.581152892 & 2.139564266 \\
\hline
\end{tabular}


INTERNATIONAL JOURNAL OF ACADEMIC RESEARCH IN BUSINESS AND SOCIAL SCIENCES Vol. 9, No. 9, September, 2019, E-ISSN: 2222-6990 @ 2019 HRMARS

\begin{tabular}{|l|l|l|l|l|l|l|}
\hline 2009 & $49,856.10$ & 251.79 & 195.71 & 4.69771829 & 2.401038478 & 2.291613017 \\
\hline 2010 & $54,612.26$ & 415.66 & 183.48 & 4.73729018 & 2.618738233 & 2.263588731 \\
\hline 2011 & $57,511.04$ & 527.18 & 131.52 & 4.75975123 & 2.721961185 & 2.119000689 \\
\hline 2012 & $59,929.89$ & 679.30 & 147.10 & 4.7776435 & 2.832061615 & 2.167612673 \\
\hline 2013 & $63,218.72$ & 828.10 & 139.73 & 4.80084571 & 2.918083834 & 2.145281329 \\
\hline 2014 & $67,152.79$ & 941.70 & 182.81 & 4.82706403 & 2.97391257 & 2.261999949 \\
\hline 2015 & $69,023.93$ & $1,060.38$ & 208.11 & 4.83899968 & 3.025462757 & 2.318292949 \\
\hline 2016 & $67,931.24$ & $1,584.11$ & 168.00 & 4.83206952 & 3.199784956 & 2.225298207 \\
\hline
\end{tabular}

Sources: CBN statistical bulletin (2016)

\section{Test Statistics}

Table 4.2.1: Unit Root Test.

ADF Unit Root test

\begin{tabular}{llllll}
\hline Variables & $\begin{array}{l}\text { ADF } \\
\text { Level }\end{array}$ & $\begin{array}{l}\text { ADF } \\
1^{\text {st }} \text { Difference }\end{array}$ & $\begin{array}{l}0.05 \text { Critical } \\
\text { Value } \\
\text { Level }\end{array}$ & $\begin{array}{l}0.05 \text { Critical } \\
\text { Value } \\
1^{\text {st }} \\
\text { Difference }\end{array}$ & $\begin{array}{l}\text { Orderof } \\
\text { Integration }\end{array}$ \\
D(LOGRGDP) & 0.097327 & -3.229356 & -2.951125 & -2.951125 & $1(1)$ \\
& & & & & \\
D(LOGPENGEX) & -1.062492 & -3.675721 & -3.065585 & -3.020686 & $1(1)$ \\
\hline
\end{tabular}

Source: Author's computation using E-views 9.0 software

This study adopted the augmented Dickey-Fully (ADF) unit root test. From the result in table 4.1 , it is evident that at level, none of the variables was stationary as their ADF values were less than the critical values at five percent level of significance. The ADF values for RGDP (0.097327), and PENGEX (1.062492) in absolute terms were less than their critical values (2.951125) and (3.065585 respectively. Based on this outcome, there was a need to difference the non-stationary time series one more time to see whether we will obtain overall stationary. At first difference, all the variables became stationary as their ADF values 3.229356, and 3.675721 became greater than their critical values 2.951125 , and 3.020686 in absolute term. Because all the variables were integrated of the same order (i.e. I (1)), cointegration analysis was justified. 
Table 4.2.3. Table showing response of Economic Growth to pension and gratuity expenditure

Dependent Variable: D(LOGRGDP)

Method: Least Squares

Date: 11/08/18 Time: 20:42

Sample (adjusted): 19822016

Included observations: 30 after adjustments

\begin{tabular}{lcccl}
\hline \hline Variable & \multicolumn{2}{l}{ Coefficient Std. Error } & t-Statistic & Prob. \\
\hline \hline C & 0.016226 & 0.003947 & 4.110835 & 0.0003 \\
& & & & \\
D(LOGPENGEX) & 0.016770 & 0.007525 & 2.228571 & 0.1401 \\
ECM(-1) & -0.108123 & 0.041613 & -2.598285 & 0.0152 \\
\hline \hline R-squared & 0.854388 & Mean dependent var & 0.019422 \\
Adjusted R-squared & 0.768355 & S.D. dependent var & 0.019874 \\
S.E. of regression & 0.018124 & Akaike info criterion & -5.059580 \\
Sum squared resid & 0.008541 & Schwarz criterion & -4.872753 \\
Log likelihood & 79.89369 & Hannan-Quinn criter. & -4.999812 \\
F-statistic & 5.956887 & Durbin-Watson stat & 1.918426 \\
Prob(F-statistic) & 0.040940 & & & \\
\hline \hline
\end{tabular}

Source: Author's computation using E-views 9.0

From the result, one percent increase in pension expenditure leads to 0.02 percent increase in gross domestic product (proxy for economic growth) in Nigeria. The probability value of pension expenditure $(0.14)$ is less than the test significant level (i.e. $P>0.05$ ). Thus, we conclude that pension expenditure has positive and non significant impact on economic growth in Nigeria. Perhaps, this outcome can be attributed to the fact that increasing pension expenditure by Nigerian government denies the nation of funds needed to develop its infrastructure. As fewer funds is invested in infrastructure development, economic activities is undermined and productivity is adversely affected thereby leading to a increase in economic growth in Nigeria. Therefore, there is a long run relationship existing with the variables of interst

The coefficient of determination (adjusted R-squared) of 0.57 shows that 57 percent of the variations in economic growth in Nigeria are due to changes in public debt servicing expenditure and pensions and gratuities expenditure. The probability F-statistic $(0.040940)$ is less the test significant level (0.05) and this indicates that the model used in the study is appropriate, reliable and significant and can be used for sound policymaking. The DurbinWatson statistic (1.92) lies outside the acceptance region and suggests that there may be absence of autocorrelation.

Finally, an important feature to notice is the coefficient of the parameter of error correction term. The coefficient of the error correction term carries the correct sign and it is statistically significant at five percent level of significance with the speed of convergence to equilibrium of 11 percent. This implies that in the short run, economic growth adjust by 11 percent of the past year's deviation from equilibrium. This is essential for maintaining long run equilibrium 
to reduce the existing disequilibrium over time. This result justifies the use of an ECM specification of the model in the study.

\section{Conclusion}

The study investigated the responsiveness of economic growth to government expenditures in Nigeria. Specifically, the study investigated how economic growth in Nigeria responds to government expenditure on pensions and gratuities Thus, government expenditure on pensions and gratuities served as the independent variables while real gross domestic product served as the dependent variable. From the empirical evidence, the study revealed that government expenditure on pensions and gratuities do positively and significantly increase economic growth in Nigeria. In conclusion, the study argued that economic growth in Nigeria responds to government expenditures .It was recommended that Government should spend more on settling pensions and gratuities as a way to increase aggregate demand and foster more economic growth in Nigeria.

\section{References}

Agu, S. U., Idike, A. N., Okwor, I, M., \& Ugwunta, D. (2014). Fiscal policy and economic growth in Nigeria: Emphasis on various components of public expenditure. Singaporean Journal of Business, Economics and Management Studies, 2(12), 37-54.

Alshahrani, S., \&Alsadiq, A. (2014). Economic growth government spending in Saudi Arabia. International Monetary Fund (IMF) Working Paper, 35.

Bazezew, B. A. (2014). Impact of government sectoral expenditure on economic growth in Ethiopia with a particular focus on agriculture, defense, education and health sectors. Thesis submitted to the School of Graduate Studies, Addis Ababa University, Ethiopia.

Bjork, G. J. (1999). The way it worked and why it won't: Structural change and the slowdown of U.S. economic growth. Westport, CT: Praeger Publications.

CBN (2016). Statistical Bulletin. Abuja: Central Bank of Nigeria.

Cornelius, M. O., Nkamare, S. E., \&Ogar, A. (2016). Government expenditure and its implications on Nigerian economy. IOSR Journal of Humanities and Social Science, 21(1), 50-55.

Gilbert, D. I., \&Kehinde, O. O. (2017). Government expenditure and economic growth in Nigeria: An analysis with dynamic Ordinary Least Squares. International Journal of Academic Research in Business and Social Sciences, 7(5), 8-26.

International Monetary Fund (2013).International Financial Statistics. Washington, D.C.: International Monetary Fund.

Kelvin, H. K., Yapatake, K. T. P., \& Abeid, A. R. (2017). Government expenditure and economic growth in Tanzania: A time series analysis. International Journal of Development and Economic Sustainability, 5(1), 11-22.

Keynes, J. M. (1936). General Theory of Employment, Interest and Money. London: Palgrave Macmilliam Publishers.

Nwaeze, C., Michael, O., \& Nwabekee, C. (2014). Financial intermediation and economic growth in Nigeria (1992-2011). The Macrotheme Review, 3(6), 124-142.

Nwankwo, D. J., Kalu, C. U., \& Chiekezie, M. O. (2017). Fiscal policy-economic growth correlates: Further evidence from Nigeria economy. International Journal of Academic Research in Business and Social Sciences, 7(1), 1-11. 
Nwaoha, W. C., Onwuka, O. O., \& Ejem, C. A. (2017). Effect of aggregated and disaggregated public spending on the Nigerian economy (1980-2015). International Journal of Economics and Financial Research, 3(4), 44-53.

Obialor, M. C. (2017). Effect of government human capital investment on economic growth in sub-Saharan Africa: Evidence from Nigeria, South Africa and Ghana (1980-2013). International Journal of Asian Social Science, 7(4), 328-339.

Okemini, E. B., \& Uranta, D. T. (2008). Poverty and criminality in the Niger-Delta region: A critical analysis. Integrated Social and Management Journal, 1(2), 1-8.

Okoro, A. S. (2013). Government spending and economic growth in Nigeria, 1980-2011. Singaporean Journal of Business Economics and Management Studies, 2(5), 81-92.

Okwo, I. M. (2011). Introduction to Public Sector Finance and Accounting. Johnkens and Willy International Ltd. Publishing Inc.

Samira, A. (2016). How government expenditure effects on economic growth in Nigeria. Pyrex Journal of Business and Finance Management Research, 2(10), 122-134.

Wendwesen, T. (2012). Impact of government sectoral spending on economic growth in Ethiopia: A particular focus on human capital and agricultural sectors. M.Sc Thesis submitted to Addis Ababa University, Ethiopia. 